\title{
EFFECTS OF STRONTIUM-DOPED BIOACTIVE GLASS ON THE DIFFERENTIATION OF CULTURED OSTEOGENIC CELLS
}

\author{
Juliane Isaac ${ }^{1,2,3}$ * , Johnny Nohra ${ }^{1,2,3}$, Jonathan Lao $^{5}$, Edouard Jallot ${ }^{5}$, Jean-Marie Nedelec ${ }^{6,7}$, Ariane Berdal ${ }^{1,2,3,4}$ and \\ Jean-Michel Sautier ${ }^{1,2,3,4}$
}

${ }^{1}$ INSERM, U872, Eq.5, Laboratoire de Physiopathologie Orale et Moléculaire, F-75006 Paris, France ${ }^{2}$ Centre de Recherche des Cordeliers, Université Pierre et Marie Curie, UMR S 872, F-75006 Paris, France ${ }^{3}$ Université Paris Descartes, UMR S 872, F-75006 Paris, France

${ }^{4}$ Université Paris 7, UFR d'Odontologie, Paris, France

${ }^{5}$ Clermont Université, Université Blaise Pascal, CNRS/IN2P3, Laboratoire de Physique corpusculaire, BP 10448, F63000 Clermont-Ferrand, France

${ }^{6}$ Clermont Université, ENSCCF, LMI, F-63177 Aubière, France

${ }^{7} \mathrm{CNRS}$, UMR 6002, F-63177 Aubière, France

\begin{abstract}
There is accumulating evidence that strontium-containing biomaterials have positive effects on bone tissue repair. We investigated the in vitro effect of a new Sr-doped bioactive glass manufactured by the sol-gel method on osteoblast viability and differentiation. Osteoblasts isolated from foetal mouse calvaria were cultured in the presence of bioactive glass particles; particles were undoped (B75) or Sr-doped with 1 wt.\% (B75-Sr1) and 5 wt.\% (B75-Sr5). Morphological analysis was carried out by contrast-phase microscopy and scanning electron microscopy (SEM). Cell viability was evaluated by the MTS assay at $24 \mathrm{~h}, 48 \mathrm{~h}$ and 72 h. At 24 h, day 6 and day 12, osteoblast differentiation was evaluated by assaying alkaline phosphatase (ALP) activity, osteocalcin (OC) secretion and gene expression of various bone markers, using Real-Time-PCR. Alizarin Red staining and ALP histoenzymatic localisation were performed on day 12. Microscopic observations and MTS showed an absence of cytotoxicity in the three investigated bioactive glasses. B75-Sr5 particles in cell cultures, in comparison with those of B75 and B75-Sr1, resulted in a significant up-regulation of Runx2, Osterix, Dlx5, collagen I, ALP, bone sialoprotein (BSP) and OC mRNA levels on day 12, which was associated with an increase of ALP activity on day 6 and OC secretion on day 12. In conclusion, osteoblast differentiation of foetal mouse calvarial cells was enhanced in the presence of bioactive glass particles containing 5 wt.\% strontium. Thus, B75-Sr5 may represent a promising bone-grafting material for bone regeneration procedures.
\end{abstract}

Keywords: Bioactive glass, strontium, osteoblast, cell differentiation, in vitro.

*Address for correspondence:

Juliane Isaac

Laboratoire de Physiopathologie Orale et Moléculaire

Centre de Recherche des Cordeliers

INSERM, UMRS 872, Equipe 5

15-21 rue de l'Ecole de Médecine,

F-75270 Paris Cedex 06, France.

Telephone Number: 33 (0)1. 43.26.94.96

FAX Number: 33 (0)1. 44.07.14.21

E-mail: isaacjuliane@yahoo.fr

\section{Introduction}

Various grafting materials are being utilised today in an attempt to repair osseous defects. The use of these materials is based on the assumption that they possess osteogenic potential, and are osteoconductive (able to support bone formation) or osteoinductive (able to induce bone formation) (Wang et al., 2005). Although autogenous bone is considered the gold standard for bone regeneration, as it is the only material that possesses these three properties, some factors may limit its use (Becker et al., 1994). In fact, associated donor site morbidity and limited intraoral supply have encouraged the development of alternative materials (Nkenke et al., 2001; Clavero and Lundgren, 2003). Synthetic grafts, allografts and xenografts are essentially osteoconductive materials that act as a scaffold for revascularization and new bone ingrowth. Among these materials, bioactive glasses are bone substitutes that are thought to have not only osteoconductivity, but also to be responsible for osteoproduction by stimulating proliferation and differentiation of osteoprogenitor cells through a direct genetic control (Hench et al., 1971; Xynos et al., 2000). The discovery of these new materials led Hench and Wilson to propose the concept of "osteostimulation" or "osteopromotion" to define this class of bioactive materials and their effects on the genetic activation of bone cells (Hench and Wilson, 1984). Bioactive glasses are surface reactive biomaterials that, when in contact with physiological fluids, release soluble ionic products that have been suggested to stimulate in vitro osteogenesis (Xynos et al., 2000; Tsigkou et al., 2009). In addition, in vivo studies have demonstrated beneficial results from their use in various clinical situations (Froum et al., 1998; Anderegg et al., 1999; Froum et al., 2002; Peltola et al., 2006). After implantation, interaction with surrounding tissues results in a time-dependent alteration of the material's surface and the formation of a hydroxyl carbonate apatite layer that is very similar to the mineral phase of bone (Hench and Paschall, 1973). More recently, a new category of sol-gel glasses has been manufactured with enhanced bioactivity and open pores enclosed in a mesoporous matrix (Xiaoxia et al., 2004; Izquierdo-Barba et al., 2008). Furthermore, bioactive glass manufactured via the sol-gel technique permits the synthesis of materials 
with higher purity and homogeneity at low temperatures (Li et al., 1991). Additives can be easily introduced during the sol-gel process to improve the bioactivity of such glasses. Indeed, improvement of the biological properties of bioactive materials can be achieved by the incorporation of ions that positively affect osteoblast behaviour and consequently enhance de novo bone formation. For example, niobium incorporation in biphasic calcium phosphate enhances the alkaline phosphatase (ALP) activity of normal human osteoblasts (NHOst), and increases the amount of calcium that is deposited with a dose-dependent effect (Tamai et al., 2007). Using zinccontaining calcium phosphate ceramics with a maintained $(\mathrm{Ca}+\mathrm{Zn}) / \mathrm{P}$ molar ratio and varying zinc contents, Ikeuchi et al. also reported enhanced ALP activity with increasing zinc content in the ceramics in both rat and human bone marrow cells (BMCs), suggesting the superiority of zinccontaining ceramics in supporting osteogenic differentiation (Ikeuchi et al., 2003).

Strontium ( $\mathrm{Sr}$ ) is a naturally occurring trace element in the human body. The total amount of $\mathrm{Sr}$ in the body of a $70 \mathrm{~kg}$ "standard" man represents $0.32 \mathrm{~g}$; a normal diet provides a daily intake of 2-4 $\mathrm{mg} \mathrm{Sr}$ per day, most of it derived from vegetables and cereals. Sr often acts similarly to $\mathrm{Ca}$ in the human body; both have strong bone-seeking properties, and $\mathrm{Sr}$ can be substituted with $\mathrm{Ca}$ in the apatitic phase of bone mineral (Vaughan, 1981). Some detrimental effects of Sr deficiency have been previously investigated. For example, caries prevalence is inversely related to $\mathrm{Sr}$ levels in water, plaque, and enamel (Curzon et al., 1982). Administration of $\mathrm{Sr}$ in moderate doses prevented caries in rats (Curzon, 1985). Among the trace metals present in human bone, Sr was the only one that was correlated with bone compression strength (Jensen et al., 1997). Furthermore, over the past few years Sr has attracted attention through its beneficial effects on bone healing. Indeed, both in vitro and in vivo studies have demonstrated stimulatory effects of $\mathrm{Sr}$ on osteoblasts and an inhibitory effect on osteoclasts, associated with an increase in bone density and resistance (Marie et al., 1993; Canalis et al., 1996; Baron and Tsouderos, 2002; Bonnelye et al., 2008). Nowadays, strontium ranelate is used as a commercial antiosteoporotic oral drug that has been proven to reduce the incidence of fractures in osteoporotic patients (Meunier $e t$ al., 2004; Reginster et al., 2008). The growing evidence of the beneficial effects of strontium on bone justifies the increasing interest in $\mathrm{Sr}$ incorporation into biomaterials for hard tissue repair. Thus, strontium-doped bioactive glasses have been recently developed via a sol-gel method that enables a better control of the reaction kinetics (Lao et al., 2008; Lao et al., 2009).

The objective of this study was to investigate the in vitro effect of strontium-doped bioactive glasses manufactured via the sol-gel process on biological events associated with osteoblast viability, proliferation and differentiation. For this purpose, we studied bone cell behaviour in the presence of three types of bioactive glasses, an undoped control (B75) and two Sr-doped bioactive glasses (B75-Sr1 and B75-Sr5), using a cell culture system from foetal mouse calvaria that closely mimics the cellular events of in vivo intramembranous bone formation process, from the stage of osteoprogenitor cell proliferation through to the stages of matrix formation and mineralisation.

\section{Materials and Methods}

\section{Preparation of the bioactive glass particles}

Glasses in the $\mathrm{SiO}_{2}-\mathrm{CaO}-\mathrm{SrO}$ system were manufactured using the sol-gel process (Jallot et al., 2009). Samples were labelled using the following convention: glasses named B75-SrX were composed of $\mathrm{SiO}_{2}(75$ wt.\%)-CaO(25-X wt.\%)-SrO(X wt.\%), respectively, with $\mathrm{X}=0,1$, and 5 wt.\%. Tetraethylorthosilicate $\left(\mathrm{Si}\left(\mathrm{OC}_{2} \mathrm{H}_{5}\right)_{4}\right)$, calcium nitrate $\mathrm{Ca}\left(\mathrm{NO}_{3}\right)_{2}, 4 \mathrm{H}_{2} \mathrm{O}$, strontium nitrate $\mathrm{Sr}\left(\mathrm{NO}_{3}\right)_{2}$ (SigmaAldrich, St. Louis, MO, USA) were mixed in ethanol in the presence of water and $\mathrm{HCl}$ under ambient pressure. The prepared sols were then transferred to an oven at $60^{\circ} \mathrm{C}$ for gelification and ageing. Four hours later, the gels obtained were heated at $125^{\circ} \mathrm{C}$ for $24 \mathrm{~h}$, then grinded to powder and stabilised at $700^{\circ} \mathrm{C}$ to achieve nitrate elimination and further densification. The corresponding heating schedule was as follows: a furnace was programmed to heat up from room temperature to $700^{\circ} \mathrm{C}$ at a rate of $10^{\circ} \mathrm{C} / \mathrm{min}$, then the samples were heated at $700^{\circ} \mathrm{C}$ for $24 \mathrm{~h}$, and finally they were allowed to cool down to room temperature. For cell cultures, bioactive glass granules were sterilised by dry heat at $180^{\circ} \mathrm{C}$ for $3 \mathrm{~h}$ in a furnace and were pre-incubated for $24 \mathrm{~h}$ in Dulbecco's Modified Eagle Medium (DMEM) (Invitrogen, San Diego, CA, USA) at a concentration of $4 \mathrm{mg} / \mathrm{mL}$ prior to the experiments.

\section{Characterisation of bioactive glasses}

The compositions (expressed in molar and weight \%) of the bioactive glass powders under study were determined by inductively coupled plasma atomic emission spectroscopy (ICP-AES) (Table 1). The ICP-AES can be applied to both liquid and solid samples. The technique allows the direct analysis of liquids. In case of a solid sample, it is first dissolved using the following procedure: the sample powder is mixed with $\mathrm{LiBO}_{3}$ and then fused in graphite crucibles at $1000^{\circ} \mathrm{C}$. A small spherical bead is

Table 1: Oxide composition (molar and weight \%) of B75, B75-Sr1 and B75-Sr5 glasses.Theoretical composition in weight are given into brackets.

\begin{tabular}{cccc}
\hline $\mathbf{m o l} \%$ & $\mathbf{B 7 5}$ & $\mathbf{B 7 5 - S r 1}$ & $\mathbf{B 7 5 - S r 5}$ \\
\hline $\mathrm{SiO}_{2}$ & 73.7 & 74 & 75.5 \\
$\mathrm{CaO}$ & 26.3 & 25.4 & 21.6 \\
$\mathrm{SrO}$ & - & 0.6 & 2.9 \\
\hline $\mathbf{w t} \%$ & & & \\
\hline $\mathrm{SiO}_{2}$ & $72.2(75)$ & $74.2(75)$ & $74.1(75)$ \\
$\mathrm{CaO}$ & $24.5(25)$ & $23.6(24)$ & $19.0(20)$ \\
$\mathrm{SrO}$ & - & $0.83(1)$ & $3.83(5)$ \\
\hline
\end{tabular}


obtained which is finally dissolved in an $\mathrm{HNO}_{3} 2 \mathrm{~N}$ acid solution. The sample solution is then introduced into the apparatus where it is transformed into an aerosol by a socalled nebulizer. An inductively-coupled plasma is used to dissociate the sample droplets into their constituent atoms or ions, exciting them to a higher energy level. They return to their ground state by emitting electromagnetic radiation of characteristic wavelengths. This light is recorded by an optical spectrometer. When calibrated against standards the technique provides a highly sensitive quantitative analysis of the original sample.

Nitrogen gas sorption analyses were performed to characterise the textural properties of the glasses. The samples were vacuum outgassed at $120^{\circ} \mathrm{C}$ for $12 \mathrm{~h}$ to remove physically adsorbed molecules such as moisture from the pores. The adsorption/desorption isotherms were recorded on a Quantachrom Autosorb-1 apparatus. The instrument determined isotherms volumetrically by a discontinuous static method at $77 \mathrm{~K}$. The surface areas were obtained by applying the Barrett-Emmett-Teller (BET) method to the $\mathrm{N}_{2}$ isotherm. The pore size distribution was determined by the Barrett-Joyner-Halanda (BJH) method on the desorption branch. Total pore volume was measured at a relative pressure $\mathrm{P} / \mathrm{P}_{0}=0.995$.

Dissolution assays were also conducted on the three glasses, in order to evaluate the ion leaching capacity of each material in the absence of cells. The bioactive glasses were first put in contact with the basal DMEM medium for $24 \mathrm{~h}$, then with the supplemented cell culture media (see Culture model and cell cultivation) at a concentration of $4 \mathrm{mg} / \mathrm{mL}$. The experiments were conducted at $37^{\circ} \mathrm{C}$ and the culture media was renewed every $72 \mathrm{~h}$. After $24 \mathrm{~h}$ and 2, 3, 4, and 6 days of interaction, $\mathrm{Si}, \mathrm{Ca}$ and $\mathrm{Sr}$ concentrations in the liquid media were determined by ICPAES analyses.

\section{Cell culture and analyses}

\section{Culture model and cell cultivation}

Osteoblastic cells were enzymatically isolated from calvaria of Swiss OF1 mouse foetuses on embryonic day 18. All procedures for the care and use of animals were conducted after approval from the regional animal experimentation ethics committee (p3/2008/043) and the French Ministry for the Environment and Research (no. 5195). Briefly, frontal and parietal bones of calvaria were aseptically dissected and bone fragments were digested with $0.25 \%$ collagenase type I (Sigma-Aldrich) in PBS for $2 \mathrm{~h}$ at $37^{\circ} \mathrm{C}$. Then cells dissociated from bone fragments were plated at a density of $2 \times 10^{4}$ cells $/ \mathrm{cm}^{2}$ in culture dishes, and grown in osteogenic medium composed of DMEM (Invitrogen), supplemented with 10\% foetal calf serum (FCS) (Invitrogen), $50 \mu \mathrm{g} / \mathrm{mL}$ ascorbic acid (SigmaAldrich), $10 \mathrm{mM} \beta$-glycerophosphate (Sigma-Aldrich), and $50 \mathrm{UI} / \mathrm{mL}$ penicillin-streptomycin (Invitrogen). The cells were maintained at $37^{\circ} \mathrm{C}$ in a fully humidified atmosphere at $5 \% \mathrm{CO}_{2}$ in air and culture medium was changed at $48 \mathrm{~h}$ intervals. The cells were allowed to proliferate in culture until subconfluence and were passaged once before use in experiments. After one day of culture, the cells reached
$80 \%$ confluence and the pre-incubated granules were added to the cultures at the concentration of $4 \mathrm{mg} / \mathrm{mL}$ of culture medium. The experiments were conducted in triplicate to minimize errors caused by the uneven distribution of particles.

Cell morphology - scanning electron microscopy (SEM) Calvarial bone cells were plated at a density of $2 \times 10^{4}$ cells/ $\mathrm{cm}^{2}$ on Thermanox Plastic coverslips (NUNC, Rochester, NY, USA) placed in a 12 -well plate. At $80 \%$ confluence, B75-Sr5 glass particles were added to cell cultures at a concentration of $4 \mathrm{mg} / \mathrm{mL}$ of culture medium. $48 \mathrm{~h}$ later, cells cultured on the plastic coverslips were fixed for $1 \mathrm{~h}$ in Karnovsky solution (4\% paraformaldehyde, 1\% glutaraldehyde) and rinsed three times with $0.2 \mathrm{M}$ sodium cacodylate buffer at $\mathrm{pH}$ 7.4. Samples were then dehydrated through a graded series of ethanol and amyl acetate solutions before critical point drying in $\mathrm{CO}_{2}$. Finally, the samples were mounted on specimen stubs and sputtercoated with gold palladium. Samples were examined on a JEOL JSM 6100 SEM (Jeol France, Croissy-Sur-Seine, France) operating at a $15 \mathrm{kV}$ accelerating voltage.

\section{Cell viability-MTS test}

Cell viability at $24 \mathrm{~h}, 48 \mathrm{~h}$ and $72 \mathrm{~h}$ was measured using The Cell Titer 96 Aqueous One Solution Cell Proliferation Assay (Promega, Madison, WI, USA). This procedure determines formazan production in living cells that are capable of reducing the MTS tetrazolium compound to coloured formazan derivatives. This intracellular bioreduction system is mostly located in the mitochondria and the amount of coloured formazan derivatives excreted into the culture medium can be measured with a microplate reader. The optical density (OD) of the cell supernatant was measured with a spectrophotometer (Precision Microplate Reader, Molecular Devices, Sunnyvale, CA, USA) at $490 \mathrm{~nm}$. Cells grown without bioactive glass served as a control.

\section{Evaluation of gene expression - real-time (RT)-PCR}

Calvarial bone cells grown in the presence of B75, B75$\mathrm{Sr} 1$ or B $75-\mathrm{Sr} 5$ glass particles were recovered at $24 \mathrm{~h}$, day 6 and day 12, and total RNA was extracted using the TriReagent kit (Euromedex, Souffelweyersheim, France), following supplier's instructions. In brief, total RNA was precipitated with isopropanol and centrifuged at $12000 \mathrm{~g}$ at $4{ }^{\circ} \mathrm{C}$. Then, the RNA pellet was washed with $75 \%$ ethanol and resuspended in RNase-free water. The concentration and the purity of total RNA in each sample were determined by light absorbance at $260 \mathrm{~nm}$ and by calculating the $\mathrm{A}_{260} /$ $\mathrm{A}_{280}$ ratio, respectively. The integrity of RNA was confirmed by electrophoresis on an agarose ethidium bromide gel. One microgram of total RNA of every sample was reverse transcribed into cDNA using 200 units of Superscript II (Invitrogen) and $250 \mathrm{ng}$ of random primers, according to the manufacturer's instructions. Real-time PCR reactions were performed using a MiniOpticon RealTime PCR Detection System (Bio-Rad Laboratory, Hercules, CA, USA). According to manufacturer's recommendations, a $15 \mu \mathrm{l}$ volume, containing $7.5 \mu \mathrm{l}$ of 
Table 2: Primers used in real-time quantification of selected gene transcripts.

\begin{tabular}{|l|l|l|l|}
\hline Gene transcript & Code & Forward primer sequence & Reverse primer sequence \\
\hline GAPDH & XM_001473623.1 & $\begin{array}{l}\text { ACCCCTTCATTGACCTC } \\
\text { AACTAC }\end{array}$ & $\begin{array}{l}\text { AGTTGTCATGGATGAC } \\
\text { CTTG }\end{array}$ \\
\hline $\begin{array}{l}\text { Dlx5 (Distal-less } \\
\text { homeobox 5) }\end{array}$ & NM_198854.1 & $\begin{array}{l}\text { CTGGCCGCTTTACAGAG } \\
\text { AAG }\end{array}$ & $\begin{array}{l}\text { CTGGTGACTGTGGCGA } \\
\text { GTTA }\end{array}$ \\
\hline $\begin{array}{l}\text { Runx2 (Runt-related } \\
\text { transcription factor 2) }\end{array}$ & NM_009820.2 & $\begin{array}{l}\text { GGACGAGGCAAGAGTT } \\
\text { TCAC }\end{array}$ & $\begin{array}{l}\text { TGCCTGCCTGGGATCT } \\
\text { GTAA }\end{array}$ \\
\hline $\begin{array}{l}\text { Osterix (Trans-acting } \\
\text { transcription factor 7) }\end{array}$ & NM_130458.2 & $\begin{array}{l}\text { CCTAGGTTATCTCCTTG } \\
\text { CATGTCT }\end{array}$ & $\begin{array}{l}\text { ATTGGGAAGCAGAAA } \\
\text { GATTAGATG }\end{array}$ \\
\hline $\begin{array}{l}\text { Collagen I (Collagen, } \\
\text { type I, alpha 1) }\end{array}$ & NM_007742.3 & $\begin{array}{l}\text { AAGATGTGCCACTCTGA } \\
\text { CTG }\end{array}$ & $\begin{array}{l}\text { ATAGGTGATGTTCTGG } \\
\text { GAGG }\end{array}$ \\
\hline $\begin{array}{l}\text { ALP (Alkaline } \\
\text { phosphatase) }\end{array}$ & NM_007431 & $\begin{array}{l}\text { CCAGCAGGTTTCTCTCT } \\
\text { TGG }\end{array}$ & $\begin{array}{l}\text { CTGGGAGTCTCATCCT } \\
\text { GAGC }\end{array}$ \\
\hline $\begin{array}{l}\text { BSP (Integrin binding } \\
\text { sialoprotein) }\end{array}$ & NM_008318.1 & $\begin{array}{l}\text { CTTACCGAGCTTATGAG } \\
\text { GATGAATA }\end{array}$ & $\begin{array}{l}\text { AAATGGTAGCCAGAT } \\
\text { GATAAGACAG }\end{array}$ \\
\hline Osteocalcin (BGLAP) & NM_031368.3 & $\begin{array}{l}\text { CTTGGTGCACACCTAGC } \\
\text { AGA }\end{array}$ & $\begin{array}{l}\text { ACCTTATTGCCCTCCT } \\
\text { GCTT }\end{array}$ \\
\hline
\end{tabular}

IQ SYBR Green Supermix (Bio-Rad), 50 ng of cDNA as template and $0.3 \mu \mathrm{M}$ of the appropriate primer-pairs (Eurogentec, Liège Belgium), was used. The final mixture was incubated in the MiniOpticon under the following conditions: $98^{\circ} \mathrm{C}$ for $10 \mathrm{~s}$ as the denaturation program, followed by 40 amplification cycles $\left(95^{\circ} \mathrm{C}\right.$ for $10 \mathrm{~s}, 60^{\circ} \mathrm{C}$ for $20 \mathrm{~s}$, and $72^{\circ} \mathrm{C}$ for $20 \mathrm{~s}$ ). Melting curve analysis was done to ensure that all transcripts under investigation were represented by a single peak, indicating specificity.

Each target gene (Table 2) was run in triplicate on a single 48-well plate, which included samples from all treatments, a no-template control, and 5 dilutions (1/10-1/ 810 ) of a control cDNA sample. The amplification curve of the target gene was created using these various dilutions to estimate gene expression of each sample. The gene expression levels were normalised to the expression of the housekeeping gene GAPDH and were expressed as fold changes relative to the expression of cells grown in the presence of B75 after 24h. Cells grown in the absence of bioactive glass served as a control.

\section{ALP histoenzymatic localisation}

Calvarial bone cells were cultured as described above, and, on day 12 , cells were fixed in fixative solution $(60 \%$ citrate buffered acetone) at room temperature and gently rinsed in deionized water for $45 \mathrm{~s}$. An alkaline-dye mixture (solution of fast blue salt RR and naphthol phosphate (Sigma-Aldrich)) was added and cell samples were incubated at room temperature and protected from direct light for $30 \mathrm{~min}$. After the histoenzymatic reaction, cells were rinsed thoroughly in deionized water for $2 \mathrm{~min}$ and examined under a phase contrast light.

\section{ALP activity assay}

Before the biochemical assay, cells cultured in the presence of B75, B75-Sr1 and B75-Sr5 were prepared at different times (24 h, day 6 and day 12), washed with DMEM (0\% FCS) on ice, and incubated in sodium-carbonatebicarbonate buffer (0.1 $\left.\mathrm{M} \mathrm{NaHCO}-\mathrm{Na}_{2} \mathrm{CO}_{3}, \mathrm{pH} 10.2\right)$. Samples were stored at $-80^{\circ} \mathrm{C}$. For all assays (in triplicate), osteoblastic cell cultures were unfrozen and incubated in an extraction buffer $\left(0.1 \mathrm{M} \mathrm{NaHCO}_{3}-\mathrm{Na}_{2} \mathrm{CO}_{3}, \mathrm{pH} 10.2,1\right.$ $\mathrm{M} \mathrm{MgCl}_{2}$ and $0.2 \%$ Igepal CA-630 (Sigma-Aldrich)) for $10 \mathrm{~min}$ and removed from their substrate with a rubber policeman. Cell extracts were sonicated before the enzyme assay to dissociate the extracellular matrix and liberate membranous ALP. The protein content was estimated using the Pierce BCA Protein Assay Kit (Pierce Chemical. Rockford, IL, USA). The specific activity of ALP was assayed in cell layers by the release of $p$-nitrophenol (pnp) from $p$-nitrophenolphosphate (Sigma-Aldrich). The optical density was read at $410 \mathrm{~nm}$ in a spectrophotometer and the enzyme activity was expressed as nmol pnp/ $\mu \mathrm{g}$ protein/ hour. Cells grown in the absence of bioactive glass served as a control.

\section{Osteocalcin protein production}

Osteocalcin (OC) protein levels in cell culture supernatants were determined by an enzyme immunoassay (EIA) kit for intact mouse OC (Biomedical Technologies, Stoughton, 
MA, USA). Cells were cultured in the presence of various bioactive glasses for periods of 6 and 12 days. Cells grown in the absence of bioactive glass served as a control. Culture medium was replaced by a serum-free medium $48 \mathrm{~h}$ prior to assaying. Supernatants were collected and assayed according to the manufacturer's instructions, and the OC level was normalised to the total cell number.

\section{Calcium deposit staining}

Calvarial bone cells were cultured in the presence of B75, B75-Sr1 and B75-Sr5 up to day 12, then fixed in 4\% (w/ v) paraformaldehyde (PFA) for $15 \mathrm{~min}$ at room temperature and stained for $15 \mathrm{~min}$ with $2 \%(\mathrm{w} / \mathrm{v})$ Alizarin Red S solution (Sigma-Aldrich) at $\mathrm{pH}$ 4.2. Cells grown in the absence of bioactive glass served as a control. The cells were washed extensively with distilled water and viewed under a phase contrast light microscope.

\section{Statistical analysis}

All experiments were performed three times using independent cell cultures, and the measurements for each biomarker at each time point were performed in triplicate. Results of the three experiments are shown, expressed as the mean \pm standard error of the mean $(\mathrm{m} \pm \mathrm{sem})$. Means for biomarkers were compared within the 3 bioactive glass groups, except for the MTS test, in which control data were also included.

For each biomarker, the statistical analyses were performed using a two-way analysis of variance (bioactive glass and time point) followed by multiple pairwise comparisons with the Holm-Bonferroni adjustment to investigate the evolution of each group of materials during the culture period (3 time-points) and for each time-point, the differences between the different groups of materials. To take into account heteroscedasticity of data, these analyses were performed on log-transformed data. The overall risk was fixed at $p<0.05$.

\section{Results}

\section{Textural properties of bioactive glasses and dissolution assays}

The physicochemical properties of bioactive glass particles with different compositions were summarised in Table 3. $\mathrm{N}_{2}$ sorption analyses showed that bioactive glasses with different compositions possessed similar BET surface area
(24-30 m²/g), BJH average pore (8.4-11.8 nm), BJH modal pore diameter $(4.6-6.1 \mathrm{~nm})$, and total pore volume (0.062$0.069)$. These results indicated that no significant textural changes occurred when doping B75 with 1 and 5 wt.\% of strontium. Additionally, particle size distribution of bioactive glasses was determined by laser granulometry on a Malvern Mastersizer S instrument (Malvern, Worcestershire, UK). Our results showed that all samples exhibit the same morphology independently of the presence of strontium, with a wide distribution spreading from a few microns up to $100 \mu \mathrm{m}$ with an average around $40 \mu \mathrm{m}$ (data not shown).

The dissolution experiments revealed that $\mathrm{Si}$ and $\mathrm{Ca}$ were released in a similar way for the three materials (Fig. 1). As demonstrated in previous studies (Ikeuchi et al., 2003), Ca was quickly released during the first $24 \mathrm{~h}$ of immersion in the basal medium (dealkalinisation stage, first step of the bioactive process) reaching $94 \mathrm{ppm}$ for B75, compared to 57 and 69 ppm for B75-Sr5 and B75$\mathrm{Sr} 1$ respectively, because B75 initially contains more $\mathrm{Ca}$. After the first $24 \mathrm{~h}$, the glasses were put in supplemented cell culture medium and $\mathrm{Ca}$ concentration decreased very slowly, and about 60 ppm Ca were present in the cell culture media after $24 \mathrm{~h}$ of interaction. Furthermore, after $144 \mathrm{~h}$ the Ca concentration became nearly equal to $50 \mathrm{ppm}$. Si was progressively released from the glasses to the medium, in a similar way for the three materials. Indeed, Si concentration continuously increased with incubation time (the "sharp decreases" observed in the Si curves corresponded to the renewing of the media after $72 \mathrm{~h}$ of interaction). Finally, in line with previous studies (Lao et al., 2008), only one significant difference was observed in the dissolution behaviour of the materials: the quantity of Sr released by B75-Sr5 was about five time greater than those released by B75-Sr1.

\section{Microscopic observations}

Observations of cultures by phase contrast microscopy allowed a step-by-step investigation of the morphological changes associated with foetal mouse osteoblast maturation culminating in bone nodule formation (Fig. 2). Throughout the observation period, no noticeable differences were observed between the experimental and control cultures, including morphological changes associated with bone nodule formation. Four hours after plating, cells started to attach and spread out on the culture dishes, exhibiting polygonal morphology (data not shown). At $80 \%$

Table 3: $\mathrm{N}_{2}$ sorption analyses of the gel-glass particles. The surface area $(\mathrm{S})$ was determined from the linear portion of the BET plot, the total pore volume $(\mathrm{V})$ was estimated from the amount of $\mathrm{N}_{2}$ adsorbed at $\mathrm{P} / \mathrm{P}_{0}=0.995$, the pore size distribution and the modal pore diameter were calculated by applying the BJH method to the $\mathrm{N}_{2}$ desorption branches, and the average pore diameter was calculated as $r=2 \mathrm{~V} / \mathrm{S}$.

\begin{tabular}{c|ccc}
\hline & B75 & B75-Sr1 & B75-Sr5 \\
\hline BET surface area $\left(\mathrm{m}^{2} / \mathrm{g}\right)$ & 30 & 24 & 28 \\
BJH average pore diameter $(\mathrm{nm})$ & 8.4 & 11.8 & 9.3 \\
BJH modal pore diameter $(\mathrm{nm})$ & 4.6 & 6.1 & 4.7 \\
\hline Total pore volume $\left(\mathrm{cm}^{3} / \mathbf{g}\right)$ & 0.062 & 0.069 & 0.066 \\
\hline
\end{tabular}



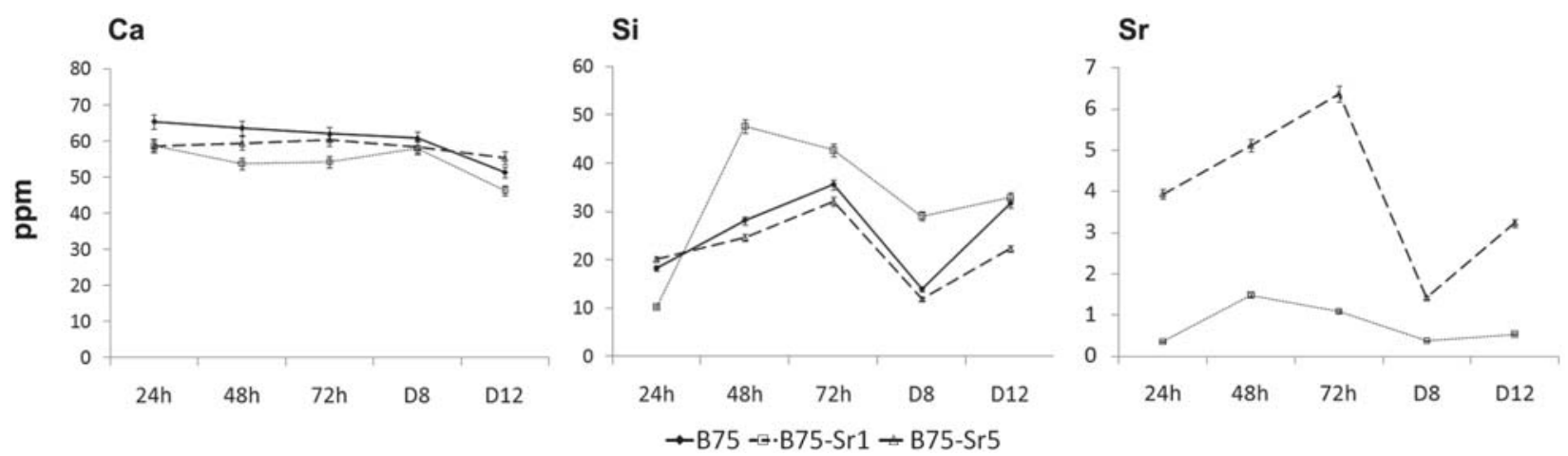

Fig. 1. ICP analyses of the evolution of $\mathrm{Ca}, \mathrm{Si}$ and $\mathrm{Sr}$ concentration (ppm) in the supplemented cell culture medium after 24 h, 48 h, 72 h, day 6, and day 12 in contact with B75, B75-Sr1 and B75-Sr5 glasses (NB: the curves break observed after $72 \mathrm{~h}$ is due to renewing of the medium). Note: initially, the cell culture medium is composed of $58 \mathrm{ppm}$ $\mathrm{Ca}$, and contains neither $\mathrm{Si}$ nor $\mathrm{Sr}$.
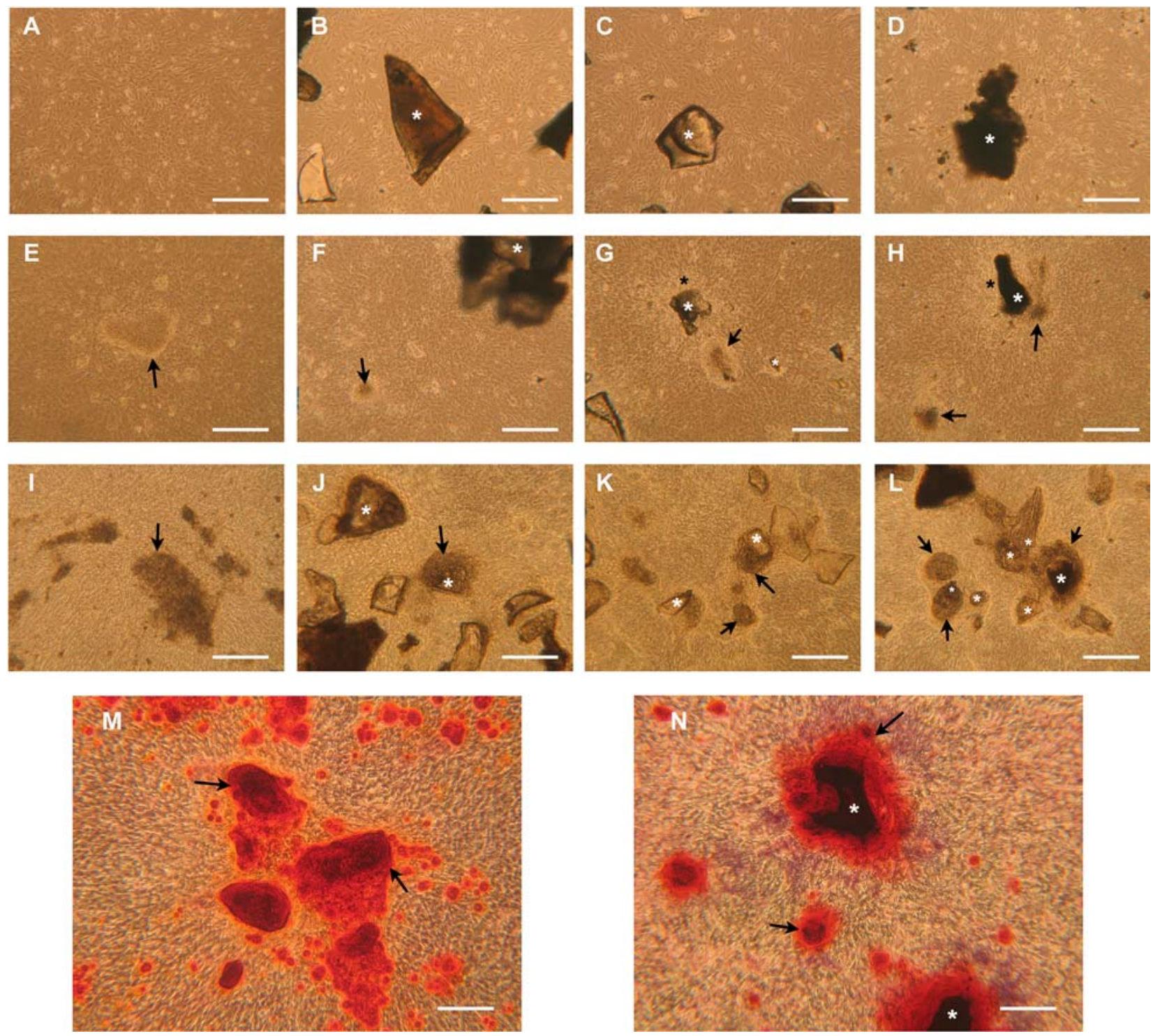

Fig. 2. Observations by phase contrast microscopy of osteoblast cultures at $24 \mathrm{~h}$ (A-D), day 6 (E-H) and day 12 (IL). Cells were grown in the absence of bioactive glass (A, E, I), or with particles (white asterix) of B75 (B, F, J), B75-Sr1 (C, G, K) and B75-Sr5 (D, H, L). (Bar =250 $\mu \mathrm{m})$. At $24 \mathrm{~h}$, particles were immobilised in the confluent cell layer (B-D). On day 6, differentiated areas were characterised by a refringent matrix around bioactive glass particles (black asterix) and some darker condensation zones (arrows) (F-H). On day 12, the differentiating areas had enlarged and dark nodules were observed (arrows) (I-L). On day 12, staining for calcium accumulation with Alizarin Red dye (M, N) showed the presence of mineralised bone nodules (arrows) in the control condition (M) and surrounding B75-Sr5 particles $\mathbf{( N )}$. (Bar $=170 \mu \mathrm{m})$. 

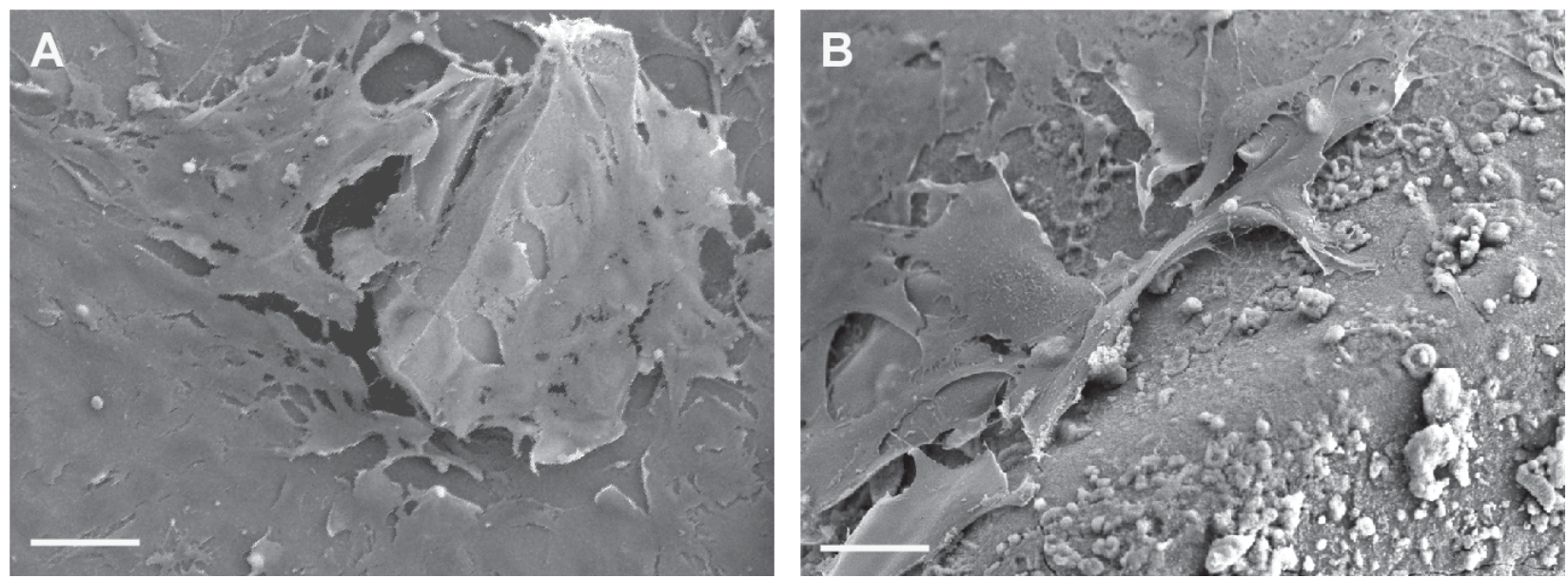

Fig. 3. Scanning electron microscopic analysis of osteoblastic cells in the presence of bioactive glass B75-Sr5 after $48 \mathrm{~h}$ of culture. Low magnification micrograph (A) showing the bound cell layer covering part of the bioactive glass particle surface $(\mathrm{Bar}=40 \mu \mathrm{m})$. Higher magnification of the bioactive glass particle surface (B) showing osteoblast attached to the substrate by means of cytoplasmic digitations $(\mathrm{Bar}=5 \mu \mathrm{m})$.

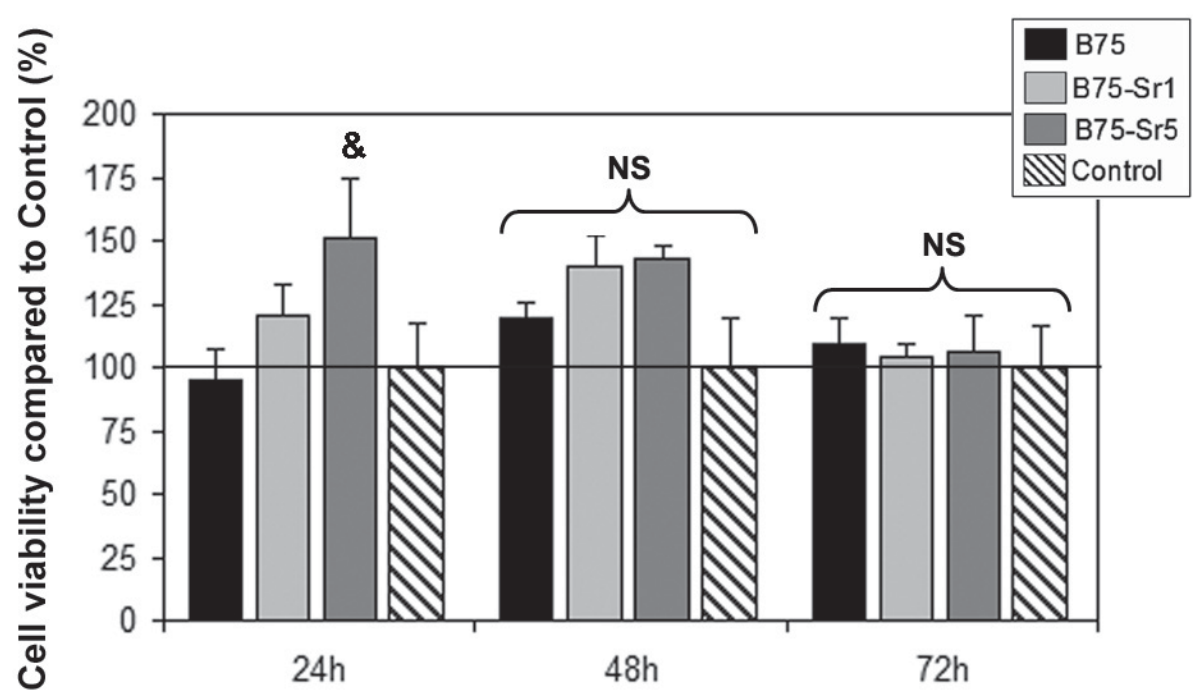

Fig. 4. MTS assay of osteoblastic cells grown with B75, B75-Sr1 and B75-Sr5 or without bioactive glass (Control) at $24 \mathrm{~h}, 48 \mathrm{~h}$ and $72 \mathrm{~h}$. Measurements in the control are set at 100\% at each time point. Bioactive glass data were expressed in percentages compared against the control. At the same time \# indicates significant difference compared to control $(p<0.05)$; \& indicates significant difference compared to B75 and * indicates significant difference compared to B75-Sr1. NS, no significant difference.

confluence, bioactive glass particles were added. After 24 $\mathrm{h}$, cells proliferated and reached confluence, thus immobilizing the granules of glass in the cell layer (Fig. 2, A-D). Thereafter, the cells formed a multilayer, and a refringent collar was observed at the periphery of the granules on day 6 (Fig. 2, E-H). On day 12 in culture, dark areas corresponding to bone nodules were observed at the periphery of the granules (Fig. 2, J-L). Some bioactive glass particles were completely surrounded by bone nodules. Alizarin Red staining revealed the presence of calcium in the bone nodules, indicating matrix mineralisation (Fig. 2, M-N).

SEM observations after 2 days of culture revealed that bone cells also colonised B75-Sr5 particle surfaces (Fig. 3A). Similar observations were obtained with the various glass particles (data not shown). Higher magnification micrographs showed that cells were anchored to particle surfaces by cytoplasmic digitations (Fig. 3B). Globular deposits were observed on the bioactive glass surface, probably resulting from ion precipitation and interaction with the culture medium.

\section{Viability assay}

Cell viability and metabolic activity were determined using the MTS assay. Foetal calvarial cells were cultured in the presence of bioactive glass particles or in control conditions, and MTS conversion was assessed after $24 \mathrm{~h}$, $48 \mathrm{~h}$ and $72 \mathrm{~h}$ (Fig. 4). At each time point, no significant differences were found between control and B75 or B75$\mathrm{Sr} 1$ conditions. However, significantly higher viability was observed at $24 \mathrm{~h}$ in the presence of B75-Sr5 particles than with B75 particles, reaching $159 \%$ of values. Nonetheless, at $48 \mathrm{~h}$ and $72 \mathrm{~h}$, no significant differences were found between B75-Sr5 and the other conditions. 

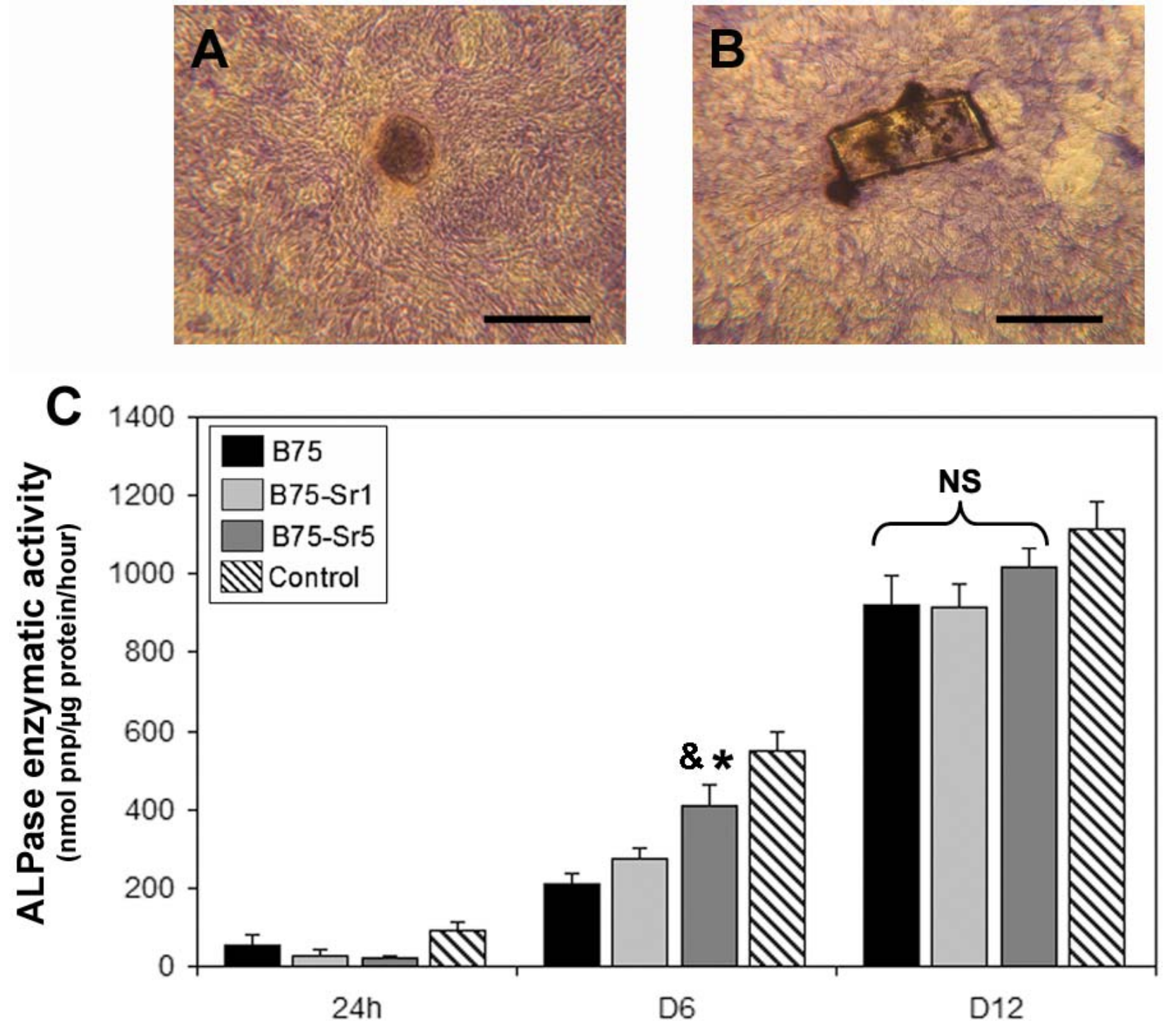

Fig. 5. Histoenzymatic localisation of alkaline phosphatase on day 12 in the control culture (A), and in the presence of B75-Sr5 particles (B) $(\mathrm{Bar}=350 \mu \mathrm{m})$. Time course of ALP-specific activity over 12 days of culture, (C) in the presence or absence (Control) of bioactive glass particles. At the same time point, \& indicates significant difference compared to B75 $(p<0.05)$ and * indicates significant difference compared to B75-Sr1. NS, no significant difference.

\begin{abstract}
ALP activity
On day 12, most osteoblastic cells were positively stained for ALP under both control and B75-Sr5 conditions (Fig. 5A,B). Furthermore, an intense staining was observed around B75-Sr5 particles (Fig. 5B). Similar staining was seen in the presence of B75 and B75-Sr1 particles (data not shown). ALP activity showed gradual and significant increases over the culture period, for all tested conditions $(p<0.05)$ (Fig. 5C). No significant differences were observed among the 3 bioactive glass groups for each time point, except on day 6 where ALP activity was significantly greater in the presence of B75-Sr5 particles than in the presence of the other particles.
\end{abstract}

\section{RT-PCR gene expression levels of specific osteogenic markers}

To investigate osteoblastic differentiation of foetal calvarial bone cells in the presence of bioactive glass particles, gene expression levels of selected osteoblast markers, including bone protein markers (Fig. 6) and osteoblastic transcription factors (Fig. 7), were determined by RT-PCR at $24 \mathrm{~h}$, day 6 and day 12 . We found that selected genes were expressed throughout the culture period.

Genes related to extracellular bone matrix proteins had similar expression patterns, with a significant increase over time for all studied conditions $(p<0.05)$ (Fig. 6). However, the magnitude of the observed increase was highly dependent on the bioactive glass being investigated. Indeed, on day 12, the expression of type I alpha 1 Collagen (Collagen I) was significantly higher in the presence of B75-Sr5 particles than in the presence of B75 and B75Sr1 particles. ALP mRNA levels were also significantly greater in the presence of B75-Sr5 at day 6 than in the presence of B75 and B75-Sr1; this was similarly observed at day 12 in comparison with B75. Finally, in the presence of B75-Sr5 particles, cells expressed significantly higher amounts of both BSP and OC mRNA at all time points than those in the presence of B75 and B75-Sr1. BSP mRNA levels were also greater in the presence of B75-Sr1 at day 6 than in the presence of B75. 


\section{Collagen I}

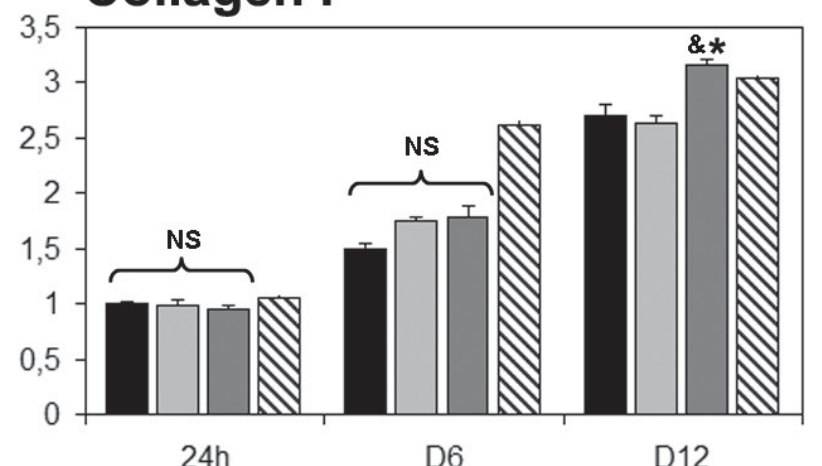

\section{BSP}

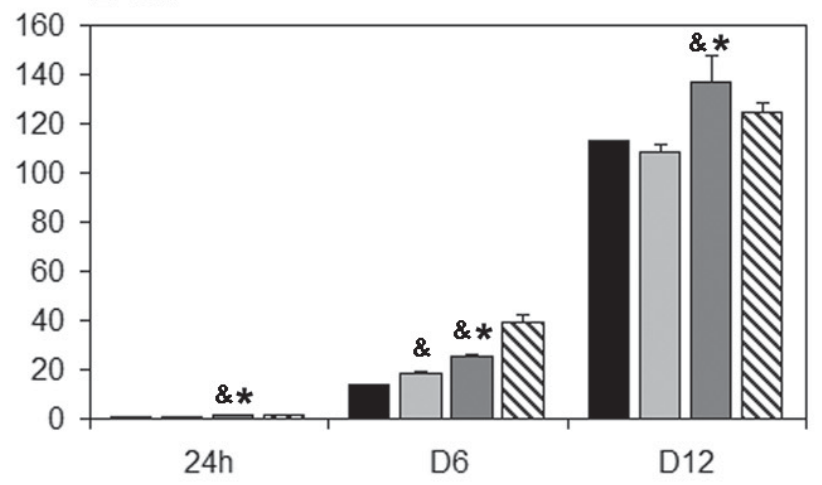

\section{ALP}

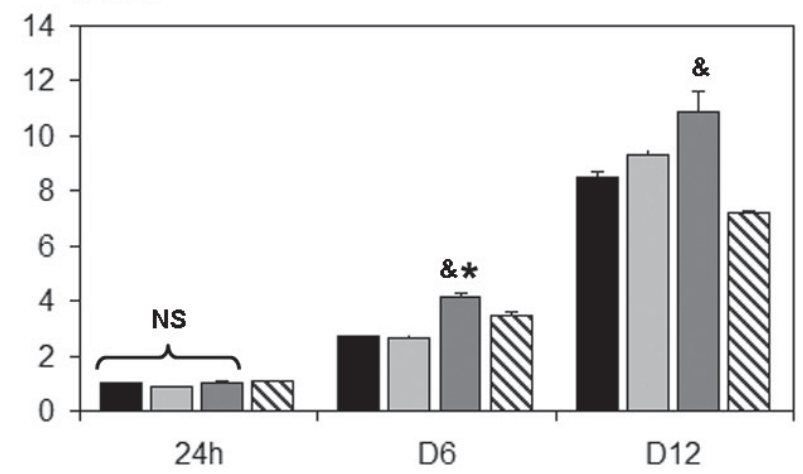

OC

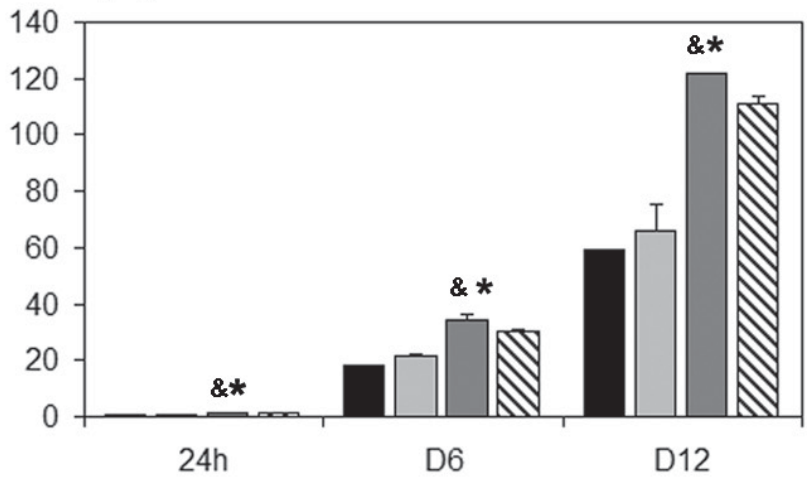

\section{B75 $\square$ B75-Sr1 $\square$ B75-Sr5 $\mathbb{N}$ Control}

Fig. 6. Real-time PCR analysis of the gene expression of selected bone protein markers at $24 \mathrm{~h}$, day 6 and day 12 by osteoblastic cells grown with B75, B75-Sr1 and B75-Sr5 particles or without bioactive glass (Control). mRNA levels of the genes of interest were normalised against the expression of the housekeeping gene GAPDH, and are represented as fold differences relative to B75 at $24 \mathrm{~h}$. At the same time point, \& indicates significant difference compared to B75 $(p<0.05)$ and * indicates significant difference compared to B75-Sr1. NS, no significant difference.

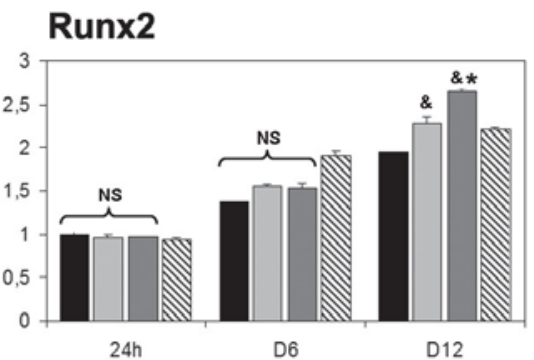

$24 \mathrm{~h}$
Osterix

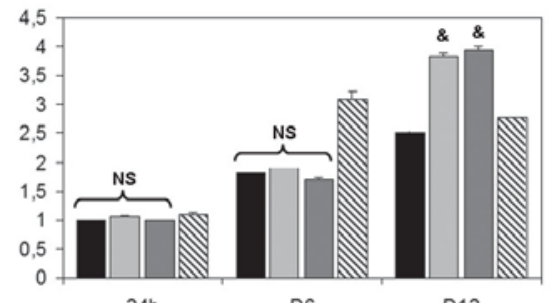

$24 \mathrm{~h}$

\section{DIx5}

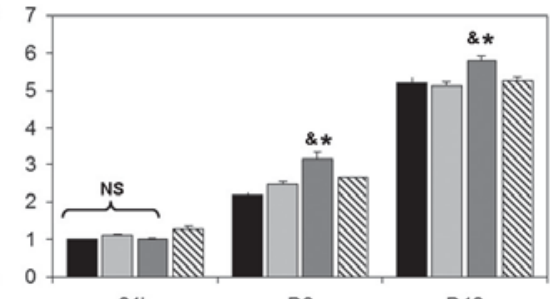

D6

B75 $\square$ B75-Sr1 $\square$ B75-Sr5 $\mathbb{W}$ Control

Fig. 7. Real-time PCR analysis of the expression of selected osteoblastic transcription factors at 24 h, day 6 and day 12 by osteoblastic cells grown with B75, B75-Sr1 and B75-Sr5 particles or without bioactive glass (Control). mRNA levels of the genes were normalised against the expression of the housekeeping gene GAPDH and are represented as fold differences relative to B75 at $24 \mathrm{~h}$. At the same time point, \& indicates significant difference compared to B75 $(p<0.05)$ and * indicates significant difference compared to B75-Sr1. NS, no significant difference.

To investigate osteoblastic differentiation of calvarial bone cells further, we also determined the expression of genes related to selected transcription factors (Fig. 7). Overall, Runx2, Osterix (Osx) and Dlx5 had similar expression profiles with all the tested materials, with mRNA levels gradually and significantly increasing up to day $12(p<0.05)$. Runx2 and Osx expressions remained comparable for all groups at $24 \mathrm{~h}$ and day 6 but on day 12 were significantly enhanced with both strontium-doped bioactive glasses. Moreover, on day 12, cells grown in the presence of B75-Sr5 had higher Runx 2 mRNA levels than those with B75-Sr1. Culture in the presence of B75-Sr5 particles resulted also in higher Dlx 5 mRNA levels on days 6 and 12 than B75 and B75-Sr1. 


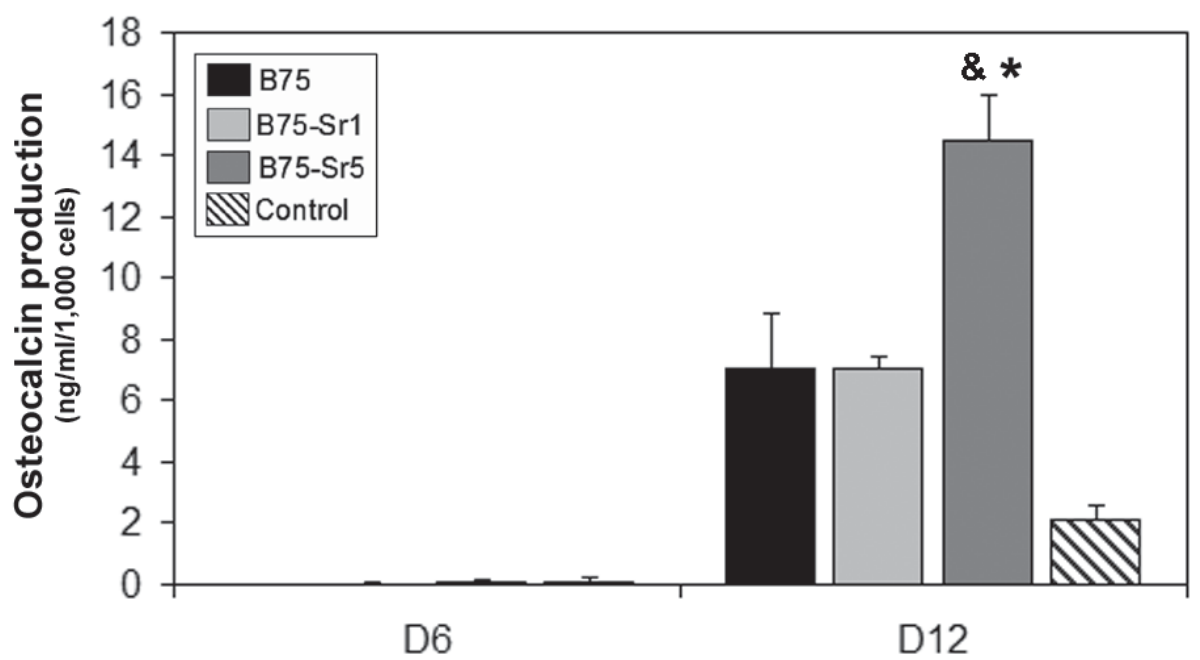

Fig. 8. Osteocalcin (OC) protein production by osteoblastic cells in the presence of bioactive glass particles (B75, B75-Sr1 or B75-Sr5) or in control condition performed by ELISA assay at days 6 and 12. Data are expressed as OC $(\mathrm{ng} / \mathrm{mL})$ secreted during $48 \mathrm{~h}$ in the serum-free medium, and normalised to the total cell count. At the same time point, \& indicates significant difference compared to B75 $(p<0.05)$ and * indicates significant difference compared to B75-Sr1.

\section{Osteocalcin secretion}

Osteocalcin protein production was assayed using an ELISA test on days 6 and 12 (Fig. 8). There was a slight secretion of $\mathrm{OC}$ on day 6 , which significantly increased on day 12 for all tested conditions $(p<0.05)$. Furthermore, although there were no significant differences observed in cells grown in the presence of B75 and B75-Sr1 on day 12 , OC secretion was significantly greater in the presence to B75-Sr5 particles than in the presence of B75 and B75Sr1.

\section{Discussion}

Bioactive glasses are a group of synthetic silica-based bioactive materials with bone-bonding properties first discovered by Larry Hench (Hench et al., 1971). Although bioactive glasses have been used for over 15 years with success in oral and maxillo-facial clinical applications (Froum et al., 1998; Peltola et al., 2006), limited benefits have been reported (Turunen et al., 2004; Wang et al., 2005). Recently, due to the growing evidence showing that strontium influences bone cells and bone metabolism in vitro and in vivo (Marie, 2006), melt-derived strontiumdoped bioactive glasses prepared from a base 45S5 bioglass have been developed and implanted in rat tibia bone marrow (Gorustovich et al., 2010). However, the affinity indices of the strontium-doped bioactive glass, i.e., the percentage of bone at the material-tissue interface, did not differ significantly with respect to $45 \mathrm{~S} 5$. New bioactive glasses have been developed using the sol-gel process to improve the biological properties of these biomaterials ( $\mathrm{Li}$ et al., 1991; Pereira et al., 1994; Hamadouche et al., 2001; Olmo et al., 2003; Gil-Albarova et al., 2004; Yan et al., 2006). The objective of this study was to evaluate the effect of new strontium-doped bioactive glasses manufactured by means of a sol-gel method on biological events associated with osteoblast differentiation. For this purpose, we used foetal mouse calvaria cells grown in the presence of sol-gel binary $\mathrm{SiO}_{2}-\mathrm{CaO}$ glasses that were undoped (B75) or doped with 1 or 5 wt.\% of strontium (B75-Sr1 and B75-Sr5), as described by Lao et al. (2009).

In vivo, bone healing can be divided into three different biological phases: osteoconduction, de novo bone formation and bone remodelling (Davies, 1998). In this study, primary foetal mouse osteoblasts were enzymatically isolated from calvaria and then cultured with bioactive glass particles with the aim of mimicking de novo bone formation occurring in the presence of bone substitutes. Cell lines often exhibit incomplete patterns of osteoblastic differentiation (Cooper et al., 1998) and various other mechanisms of attachment (Kilpadi et al., 2004); thus, cell cultures obtained through the enzymatic digestion of bones are considered to be more relevant for investigating phenotypic changes occurring during the process of osteoblastic differentiation. Indeed, if cultured in osteogenic medium, osteogenic cells from these cultures support the proliferation and govern the commitment of osteoprogenitor cells to mature osteoblasts (Nefussi et al., 1985; Owen et al., 1990).

In the present study, microscopic observations of cultures and the MTS viability assay revealed that the presence of bioactive glass particles did not affect viability of bone cells, when compared with control cultures without biomaterials. SEM also revealed that calvarial bone cells colonised the surface of all bioactive glass particles tested. Taken together, these results suggested an absence of cytotoxicity in the three investigated bioactive glass compositions.

Osteoblast differentiation and subsequent bone formation is a gradual and well orchestrated process associated with characteristic temporal modifications in gene expression and characterised in vitro by three developmental stages: 1) proliferation, 2) extracellular matrix production and maturation, and 3) matrix mineralisation (Owen et al., 1990; Garcia et al., 2002). 
We used this paradigm to investigate osteoblast differentiation occurring in the presence of bioactive glass particles, by monitoring bone gene expression patterns using real-time RT-PCR and extracellular matrix protein production.

We first investigated gene expression of two early osteoblast differentiation markers: Collagen I, the major organic component of the bone extracellular matrix, and ALP, a cell membrane-bound enzyme that is thought to be associated with osteoblast differentiation and phosphate metabolism (Bellows et al., 1991). Both Collagen I and ALP mRNA levels gradually and significantly increased over the culture period in the various cultures. These observations, in addition to the gradual increase of ALP activity throughout the culture period and the presence of several positively stained ALP cells, demonstrated the commitment toward osteoblast differentiation for all culture conditions. These observations were further confirmed by the gene expression levels of Runx2, Osterix (Osx) and Dlx5, three transcription factors strongly involved in skeletal formation and bone repair (Ferguson et al., 1999; Devlin and Sloan, 2002). Runx2 (cbfa1) and Osx are transcription factors required for osteoblast differentiation and bone formation. Thus, Runx 2 or Osx gene invalidation in mice results in the absence of a bone skeleton (Komori et al., 1997; Nakashima et al., 2002), whereas forced expression stimulates transcription of both early and late bone-marker genes (Ducy et al., 1997; Tu et al., 2006). Furthermore, Runx 2 is expressed in Osxdeficient mice, indicating that Osx acts downstream from Runx2 (Nakashima et al., 2002). Dlx5, a member of the Dlx family (Distal Less homeobox), is a homeoboxcontaining transcription factor, acting upstream from Runx2 and Osterix during osteoblast differentiation (Ryoo et al., 2006). Dlx5 levels gradually increased during osteoblast differentiation (Hassan et al., 2004) and its overexpression stimulates the transcription of several bonemarker genes, such as Collagen I, ALP, osteopontin and OC (Tadic et al., 2002). In this study, the Runx2, Osterix and Dlx 5 genes were expressed throughout the culture period, and the expression of which significantly increased over time.

In the ordered hierarchical sequence of events occurring during osteoblast differentiation and maturation, collagen I biosynthesis and ALP activity are followed by the deposition of BSP, an RGD-containing glycoprotein; this is followed by osteocalcin synthesis, a protein considered to be the most specific marker for mature osteoblasts (Lian et al., 1989). In this study, both BSP and OC showed similar gene expression patterns, with a significant increased expression throughout the 12 days of culture, for all investigated conditions. In addition, the secretion of osteocalcin in culture medium had a similar profile to that of OC mRNA levels, in which a significant increase was observed over the culture period.

Interestingly, quantitative analysis also revealed that all the investigated biomarkers were significantly affected by bioactive glass strontium content. Indeed, the MTS assay showed a significant increase in the presence of B75$\mathrm{Sr} 5$ particles at $24 \mathrm{~h}$ suggesting a positive effect on cell viability. The presence of B75-Sr5 particles was also associated with a significant stimulation of both early and late osteoblast markers at the mRNA and protein levels in comparison with undoped B75 particles. Indeed, gene expression of Runx2, Osx, Dlx5, Collagen I, ALP, BSP and $\mathrm{OC}$ was up-regulated on day 12 , whereas, at the protein level, ALP activity was increased on day 6 and OC secretion, on day 12 . Thus, calvarial bone cells cultured in the presence of B75-Sr5 particles showed greater osteoblast differentiation than those cultured with undoped bioactive glasses.

We suggested that the stimulation effect on calvarial bone cell differentiation observed in the presence of B75$\mathrm{Sr} 5$ particles is due to strontium ions released from bioactive glass particles into the culture media. Indeed, according to ICP analyses, the quantities of Si and $\mathrm{Ca}$ released in the culture media during the first six days of culture were similar for the three tested bioactive glass particles. On the contrary, Sr concentration in cell culture media was strongly affected during the first three days of culture by bioactive glass strontium content. Indeed, strontium concentration in the cell culture media is equal to 1 and $6 \mathrm{ppm}$ after $72 \mathrm{~h}$ of interaction with B75-Sr1 and B75-Sr5, respectively. Moreover, mRNA levels of some bone markers were also greater in the presence of B75Sr1 particles than in the presence of undoped bioactive glass, but our overall findings showed that B75-Sr1 particles have a limited effect on osteoblast differentiation when compared to B75-Sr5. These findings suggested a strontium dose-dependent effect on osteoblast differentiation. This hypothesis were in line with our ICP analyses and previous ones performed by Lao et al. (Lao et al., 2009), showing that the release of strontium ions during the first days of cell culture by B75-Sr5 particles was about 5-fold greater than that by B75Sr1.

Our results are in agreement with previous studies showing that strontium ions enhance bone cell replication and osteoblast differentiation in vitro (Canalis et al., 1996) with a dose-dependent effect, both when directly administrated in osteoblastic cell culture (Atkins et al., 2009; Peng et al., 2009) and when incorporated into calcium phosphate biomaterials (Qiu et al., 2006; Xue et al., 2006; Panzavolta et al., 2008; Capuccini et al., 2009; Gentleman et al., 2010).

\section{Conclusions}

Our findings indicated that calcium being substituted for strontium in a $5 \mathrm{wt} . \%$ composition in binary sol-gel bioactive glasses had a beneficial effect on foetal mouse calvarial bone cells. Indeed, osteoblast differentiation was enhanced in the presence of B75-Sr5, as shown by greater ALP activity and OC secretion and the up-regulation of Runx2, Osx, Dlx5, collagen I, ALP, BSP and OC mRNA levels, with respect to undoped B75 and the bioactive glass with a lower Sr content (B75-Sr1). Thus, B75-Sr5 bioactive glass may be a promising bone-graft material for bone regeneration procedures in oral and maxillo-facial clinical applications. Indeed, this bioactive glass combines 
strontium-induced biological stimulation in osteoblastic cells with the advantages of the sol-gel process, such as increased porosity and bioactivity.

\section{Acknowledgements}

This study was supported by the Agence Nationale de la Recherche (ANR) ( ${ }^{\circ}$ ANR-05-NANO-040). The authors thank Dr. Marcel Debray (Laboratory of Biomathematics, University of Paris Descartes) for statistical help, and David Montero and Audrey Asselin for technical assistance. This study represents part of the dissertation of Juliane Isaac's PhD degree at the University Paris Descartes, France.

\section{References}

Anderegg CR, Alexander DC, Freidman M (1999) A bioactive glass particulate in the treatment of molar furcation invasions. J Periodontol 70: 384-387.

Atkins GJ, Welldon KJ, Halbout P, Findlay DM (2009) Strontium ranelate treatment of human primary osteoblasts promotes an osteocyte-like phenotype while eliciting an osteoprotegerin response. Osteoporos Int 20: 653-664.

Baron R, Tsouderos Y (2002) In vitro effects of S129112 on osteoclast function and bone marrow macrophage differentiation. Eur J Pharmacol 450: 11-17.

Becker W, Becker BE, Caffesse R (1994) A comparison of demineralized freeze-dried bone and autologous bone to induce bone formation in human extraction sockets. J Periodontol 65: 1128-1133.

Bellows CG, Aubin JE, Heersche JN (1991) Initiation and progression of mineralization of bone nodules formed in vitro: the role of alkaline phosphatase and organic phosphate. Bone Miner 14: 27-40.

Bonnelye E, Chabadel A, Saltel F, Jurdic P (2008) Dual effect of strontium ranelate: stimulation of osteoblast differentiation and inhibition of osteoclast formation and resorption in vitro. Bone 42: 129-138.

Canalis E, Hott M, Deloffre P, Tsouderos Y, Marie PJ (1996) The divalent strontium salt S12911 enhances bone cell replication and bone formation in vitro. Bone 18: 517 523.

Capuccini C, Torricelli P, Boanini E, Gazzano M, Giardino R, Bigi A (2009) Interaction of Sr-doped hydroxyapatite nanocrystals with osteoclast and osteoblastlike cells. J Biomed Mater Res 89: 594-600.

Clavero J, Lundgren S (2003) Ramus or chin grafts for maxillary sinus inlay and local onlay augmentation: comparison of donor site morbidity and complications. Clin Impl Dent Rel Res 5: 54-160.

Cooper LF, Masuda T, Yliheikkila PK, Felton DA (1998) Generalizations regarding the process and phenomenon of osseointegration. Part II. In vitro studies. Int J Oral Maxillofac Impl 13: 163-174.

Curzon ME (1985) The relation between caries prevalence and strontium concentrations in drinking water, plaque, and surface enamel. J Dent Res 64: 1386-1388.

Curzon ME, Ashrafi MH, Spector PC (1982) Effects of strontium administration on rat molar morphology. Arch Oral Biol 27: 667-671.
Davies JE (1998) Mechanisms of endosseous integration. Int J Prosthodont 11: 391-401.

Devlin H, Sloan P (2002) Early bone healing events in the human extraction socket. Int J Oral Maxillofac Surg 31: 641-645.

Ducy P, Zhang R, Geoffroy V, Ridall AL, Karsenty G (1997) Osf2/Cbfa1: a transcriptional activator of osteoblast differentiation. Cell 89: 747-754.

Ferguson C, Alpern E, Miclau T, Helms JA(1999) Does adult fracture repair recapitulate embryonic skeletal formation? Mech Dev 87: 57-66.

Froum SJ, Weinberg MA, Tarnow D (1998) Comparison of bioactive glass synthetic bone graft particles and open debridement in the treatment of human periodontal defects. A clinical study. J Periodontol 69: 698709.

Froum S, Cho SC, Rosenberg E, Rohrer M, Tarnow D (2002) Histological comparison of healing extraction sockets implanted with bioactive glass or demineralized freeze-dried bone allograft: a pilot study. J Periodontol 73: 94-102.

Garcia T, Roman-Roman S, Jackson A, Theilhaber J, Connolly T, Spinella-Jaegle S, Kawai S, Courtois B, Bushnell S, Auberval M, Call K, Baron R (2002) Behavior of osteoblast, adipocyte, and myoblast markers in genomewide expression analysis of mouse calvaria primary osteoblasts in vitro. Bone 31: 205-211.

Gentleman E, Fredholm YC, Jell G, Lotfibakhshaiesh N, O’Donnell MD, Hill RG, Stevens MM (2010) The effects of strontium-substituted bioactive glasses on osteoblasts and osteoclasts in vitro. Biomaterials 31: 39493956.

Gil-Albarova J, Garrido-Lahiguera R, Salinas AJ, Román J, Bueno-Lozano AL, Gil-Albarova R, Vallet-Regí $\mathrm{M}$ (2004) The in vivo performance of a sol-gel glass and a glass-ceramic in the treatment of limited bone defects. Biomaterials 25: 4639-4645.

Gorustovich AA, Steimetz T, Cabrini RL, Porto Lopez JM (2010) Osteoconductivity of strontium-doped bioactive glass particles: A histomorphometric study in rats. J Biomed Mater Res 92: 232-237.

Hamadouche M, Meunier A, Greenspan DC, Blanchat C, Zhong JP, La Torre GP, Sedel L (2001) Long-term in vivo bioactivity and degradability of bulk sol-gel bioactive glasses. J Biomed Mater Res 54: 560-566.

Hassan MQ, Javed A, Morasso MI, Karlin J, Montecino M, van Wijnen AJ, Stein GS, Stein JL, Lian JB (2004) Dlx3 transcriptional regulation of osteoblast differentiation: temporal recruitment of Msx2, Dlx3, and Dlx 5 homeodomain proteins to chromatin of the osteocalcin gene. Mol Cell Biol 24: 9248-9261.

Hench LL, Paschall HA (1973) Direct chemical bond of bioactive glass-ceramic materials to bone and muscle. J Biomed Mater Res 7: 25-42.

Hench LL, Wilson J (1984) Surface-active biomaterials. Science 226: 630-636.

Hench LL, Splinter RJ, Allen WC, Greenlee TK (1971) Bonding mechanism at the interface of ceramic prothetic materials. Part I. J Biomed Mater Res Symp 2: 117-141.

Ikeuchi M, Ito A, Dohi Y, Shimaoka H, Yonemasu K, Tateishi T (2003) Osteogenic differentiation of cultured 
rat and human bone marrow cells on the surface of zincreleasing calcium phosphate ceramics. J Biomed Mater Res 67: 1115-1122.

Izquierdo-Barba I, Arcos D, Sakamoto Y, Terasaki O, López-Noriega A, Vallet-Regí M (2008) High-performance mesoporous boceramics mimicking bone mineralization. Chem Mater 20: 3191-3198.

Jallot E, Lao J, Nedelec JM, Sautier JM, Isaac J (2009) Strontium-doped bioactive glasses. U.S. Patent 20090227594 (A2).

Jensen J-EB, Stang JH, Kringsholm B, Pritzl G, Sørensen OH (1997) Relationship between trace element content and mechanical bone strength. Bone 20: 104S.

Kilpadi KL, Sawyer AA, Prince CW, Chang PL, Bellis SL (2004) Primary human marrow stromal cells and Saos2 osteosarcoma cells use different mechanisms to adhere to hydroxylapatite. J Biomed Mater Res 68: 273-285.

Komori T, Yagi H, Nomura S, Yamaguchi A, Sasaki K, Deguchi K, Shimizu Y, Bronson RT, Gao YH, Inada M, Sato M, Okamoto R, Kitamura Y, Yoshiki S, Kishimoto $\mathrm{T}$ (1997) Targeted disruption of Cbfa1 results in a complete lack of bone formation owing to maturational arrest of osteoblasts. Cell 89: 755-764.

Lao J, Jallot E, Nedelec JM (2008) Strontiumdelivering glasses with enhanced bioactivity : a new biomaterial for anti-osteoporotic applications ? Chem Mater 20: 4969-4973.

Lao J, Nedelec JM, Jallot E (2009) New strontiumbased bioactive glasses: Physicochemical reactivity and delivering capability of biologically active dissolution products. J Mater Chem 19: 2940-2949.

Li R, Clark AE, Hench LL (1991) An investigation of bioactive glass powders by sol-gel processing. J Appl Biomater 2: 231-239.

Lian JB, Stein GS, Stewart C, Puchacz E, Mackowiak S, Aronow M, Von Deck M, Shalhoub V (1989) Osteocalcin: characterization and regulated expression of the rat gene. Connect Tissue Res 21: 61-68.

Marie PJ (2006) Strontium ranelate: a physiological approach for optimizing bone formation and resorption. Bone 38: S10-14.

Marie PJ, Hott M, Modrowski D, Graulet AM, Gueris J (1993) An uncoupling agent containing strontium prevents bone loss by depressing bone resorption and maintaining bone formation in estrogen-deficient rats. J Bone Miner Res 8: 607-615.

Meunier PJ, Roux C, Seeman E, Ortolani S, Badurski JE, Spector TD, Cannata J, Balogh A, Lemmel EM, PorsNielsen S, Rizzoli R, Genant HK, Reginster JY (2004) The effects of strontium ranelate on the risk of vertebral fracture in women with postmenopausal osteoporosis. New Engl J Med 350: 459-468.

Nakashima K, Zhou X, Kunkel G, Zhang Z, Deng JM, Behringer RR, de Crombrugghe B (2002) The novel zinc finger-containing transcription factor osterix is required for osteoblast differentiation and bone formation. Cell 108: 17-29.

Nefussi JR, Boy-Lefevre ML, Boulekbache H, Forest N (1985) Mineralization in vitro of matrix formed by osteoblasts isolated by collagenase digestion. Differentiation 29: 160-168.
Nkenke E, Schultze-Mosgau S, Radespiel-Troger M, Kloss F, Neukam FW (2001) Morbidity of harvesting of chin grafts: a prospective study. Clin Oral Impl Res 12: 495-502.

Olmo N, Martin AI, Salinas AJ, Turnay J, Vallet-Regi M, Lizarbe MA (2003) Bioactive sol-gel glasses with and without a hydroxycarbonate apatite layer as substrates for osteoblast cell adhesion and proliferation. Biomaterials 24: 3383-3393.

Owen TA, Aronow M, Shalhoub V, Barone LM, Wilming L, Tassinari MS, Kennedy MB, Pockwinse S, Lian JB, Stein GS (1990) Progressive development of the rat osteoblast phenotype in vitro: reciprocal relationships in expression of genes associated with osteoblast proliferation and differentiation during formation of the bone extracellular matrix. J Cell Physiol 143: 420-430.

Panzavolta S, Torricelli P, Sturba L, Bracci B, Giardino R, Bigi A (2008) Setting properties and in vitro bioactivity of strontium-enriched gelatin-calcium phosphate bone cements. J Biomed Mater Res 84: 965-972.

Peltola M, Aitasalo K, Suonpaa J, Varpula M, Yli-Urpo A (2006) Bioactive glass S53P4 in frontal sinus obliteration: a long-term clinical experience. Head \& Neck 28: 834-841.

Peng S, Zhou G, Luk KD, Cheung KM, Li Z, Lam WM, Zhou Z, Lu WW (2009) Strontium promotes osteogenic differentiation of mesenchymal stem cells through the Ras/MAPK signaling pathway. Cell Physiol Biochem 23: 165-174.

Pereira MM, Clark AE, Hench LL (1994) Calcium phosphate formation on sol-gel-derived bioactive glasses in vitro. J Biomed Mater Res 28: 693-698.

Qiu K, Zhao XJ, Wan CX, Zhao CS, Chen YW (2006) Effect of strontium ions on the growth of ROS17/2.8 cells on porous calcium polyphosphate scaffolds. Biomaterials 27: 1277-1286.

Reginster JY, Felsenberg D, Boonen S, Diez-Perez A, Rizzoli R, Brandi ML, Spector TD, Brixen K, Goemaere S, Cormier C, Balogh A, Delmas PD, Meunier PJ (2008) Effects of long-term strontium ranelate treatment on the risk of nonvertebral and vertebral fractures in postmenopausal osteoporosis: Results of a five-year, randomized, placebo-controlled trial. Arthritis Rheum 58: 1687-1695.

Ryoo HM, Lee MH, Kim YJ (2006) Critical molecular switches involved in BMP-2-induced osteogenic differentiation of mesenchymal cells. Gene 366: 51-57.

Tadic T, Dodig M, Erceg I, Marijanovic I, Mina M, Kalajzic Z, Velonis D, Kronenberg MS, Kosher RA, Ferrari D, Lichtler AC (2002) Overexpression of Dlx 5 in chicken calvarial cells accelerates osteoblastic differentiation. J Bone Miner Res 17: 1008-1014.

Tamai M, Isama K, Nakaoka R, Tsuchiya T (2007) Synthesis of a novel beta-tricalcium phosphate/ hydroxyapatite biphasic calcium phosphate containing niobium ions and evaluation of its osteogenic properties. J Artif Organs 10: 22-28.

Tsigkou O, Jones JR, Polak JM, Stevens MM (2009) Differentiation of fetal osteoblasts and formation of mineralized bone nodules by $45 \mathrm{~S} 5$ Bioglass conditioned 
medium in the absence of osteogenic supplements. Biomaterials 30: 3542-3550.

Tu Q, Valverde P, Chen J (2006) Osterix enhances proliferation and osteogenic potential of bone marrow stromal cells. Biochem Biophys Res Commun 341: $1257-$ 1265 .

Turunen T, Peltola J, Yli-Urpo A, Happonen RP (2004) Bioactive glass granules as a bone adjunctive material in maxillary sinus floor augmentation. Clin Oral Impl Res 15: $135-141$.

Vaughan J (1981) The Physiology of Bone, 3rd ed. Clarendon Press, Oxford.

Wang HL, Greenwell H, Fiorellini J, Giannobile W, Offenbacher S, Salkin L, Townsend C, Sheridan P, Genco RJ; Research, Science and Therapy Committee (2005) Periodontal regeneration. J Periodontol 76: 1601-1622.

Xiaoxia Y, Chengzhong Y, Xufeng Z, Jiawei T, Dongyuan Z (2004) Highly ordered mesoporous bioactive glasses with superior in vitro bone-forming bioactivities. Angew Chemie Int Ed 43: 5980-5984.

Xue W, Moore JL, Hosick HL, Bose S, Bandyopadhyay A, Lu WW, Cheung KM, Luk KD (2006) Osteoprecursor cell response to strontium-containing hydroxyapatite ceramics. J Biomed Mater Res 79: 804-814.

Xynos ID, Edgar AJ, Buttery LD, Hench LL, Polak JM (2000) Ionic products of bioactive glass dissolution increase proliferation of human osteoblasts and induce insulin-like growth factor II mRNA expression and protein synthesis. Biochem Biophys Res Commun 276: 461-465.

Yan X, Huang X, Yu C, Deng H, Wang Y, Zhang Z, Qiao S, Lu G, Zhao D (2006) The in vitro bioactivity of mesoporous bioactive glasses. Biomaterials 27: 33963403.

\section{Discussion with Reviewer}

Reviewer I: In this study, strontium is used for doping of bioglasses in order to affect their biological performance. A number of other ions have also been suggested to be involved in processes related to bone formation and remodelling. Please comment whether the system presented here would be suitable for other cations, and how it should be adjusted in order to be applicable to anions?

Authors: A key advantage of the sol-gel process over the classical melting route is the glass that can be obtained in a wide variety of composition, while preserving or even enhancing the initial bioactive properties. The high versatility inherent to the sol-gel process allows easy variation of the nature of the doping ion and of its concentration, combined with a good chemical homogeneity. Doping the glasses with trace elements that are naturally present in bone and/or of biological interest can thus be achieved conveniently with the sol-gel technique; the systems studied in this article are easily tunable and other ions can be introduced in the glass matrix simply by adding the right salt/component during the mixing of the sol. In our research group we are currently studying glasses doped with $\mathrm{Mg}$, or $\mathrm{Zn}$. Other ions such as $\mathrm{Ag}^{+}, \mathrm{Mn}^{2+}$, and $\mathrm{F}^{-}$are of interest and could be incorporated without any difficulty. 